\title{
PENGARUH PERSEPSI PEMILIK DAN PENGETAHUAN AKUNTANSI PELAKU USAHA KECIL DAN MENENGAH TERHADAP PENGGUNAAN INFORMASI AKUNTANSI
}

\author{
Oleh : \\ Heriston Sianturi \\ dan \\ Nurul Fathiyah \\ Fakultas Ekonomi Program Studi Akuntansi \\ Universitas Satya Negara Indonesia
}

\begin{abstract}
ABSTRAK
Di banyak penelitian, kontribusi pelaku usaha kecil dan menengah (UKM) terhadap perekonomian memang telah terbukti, namun di sisi lain pelaku usaha skala ini juga masih banyak menghadapi masalah, dan salah satunya adalah dalam mengelola keuangannya, terutama dalam menggunakan informasi akuntansi dalam pengambilan berbagai keputusannya. Persepsi pengelola diduga kuat menjadi salah satu kunci permasalahan ini. Penelitian ini bertujuan mendapatkan informasi mengenai perspsi dan pengetahuan akuntansi pelaku UKM, dan pengaruhnya pada penggunaan informasi akuntansi untuk pengambilan keputusan.

Penelitian ini dilakukan dengan menggunakan objek pelaku UKM di wilayah Jakarta Barat, yang dipilih dan disurvey secara purposive sampling. Penelitian ini menggunakan Uji Asumsi Klasik yaitu Uji Normalitas, Uji Multikolinieritas, Uji Auto Korelasi dan Uji Heteroskedastisitas, analisis Korelasi, analisis Regresi Linier Berganda dan Uji Hipotesis.

Hasil penelitian ini secara parsial menunjukkan bahwa pengetahuan akuntansi berpengaruh signifikan dan positif terhadap penggunaan informasi akuntansi sedangkan persepsi pemilik tidak berpengaruh signifikan dan negatif terhadap penggunaan informasi akuntansi. Sedangkan secara simultan persepsi pemilik dan pengetahuan akuntansi secara bersama-sama berpengaruh signifikan dan positif terhadap penggunaan informasi akuntansi.
\end{abstract}

Kata kunci: Persepsi Pemilik UKM, Pengetahuan Akuntansi, dan Informasi Akuntansi. 


\section{PENDAHULUAN}

Usaha Kecil dan Menengah (UKM) memiliki peranan penting bagi masyarakat di tengah krisis ekonomi. Dengan memupuk UKM diyakini akan dapat dicapai pemulihan ekonomi. UKM sendiri pada dasarnya sebagian besar bersifat informal dan karena itu cenderung lebih mudah untuk dimasuki oleh pelaku-pelaku usaha yang baru.

Indonesia merupakan salah satu negara berkembang, dimana sebuah negara berkembang sangat fokus akan pembangunan dan pertumbuhan ekonomi kearah yang lebih baik. Salah satu bentuk usaha yang memberi kontribusi terhadap pertumbuhan dan perkembangan ekonomi di Indonesia adalah Usaha Kecil dan Menengah (UKM).

Peranan UKM di Indonesia sangat besar, tidak hanya dalam hal penyerapan tenaga kerja yang melebihi 90\% namun juga kontribusinya terhadap GDP Indonesia yang lebih dari 50\% selama tahun 2012. Pertumbuhan ekonomi Indonesia sepanjang 2009 hingga 2012 rata-rata mencapai 5,9\%. Sedangkan perkembangan UKM selama tahun 2013 telah mencapai 55,2 juta yang tersebar di seluruh Indonesia serta mewakili lebih dari $90 \%$ bisnis di Indonesia dan memberikan kontribusi sebesar 57\% terhadap PDB Indonesia.

Informasi akuntansi sangat bermanfaat bagi UKM, karena merupakan alat yang digunakan oleh pengguna informasi untuk pengambilan keputusan. Informasi akuntansi dapat digunakan untuk mengukur dan mengkomunikasikan informasi keuangan perusahaan yang sangat diperlukan oleh pihak manajemen dalam merumuskan berbagai keputusan untuk memecahkan permasalahan yang dihadapi. Selain itu informasi akuntansi juga berguna dalam rangka menyusun berbagai proyeksi, misalnya proyeksi kebutuhan uang kas dimasa yang akan datang, mengontrol biaya, mengukur dan meningkatkan produktivitas dan memberikan dukungan terhadap proses produksi.

Dalam kenyataannya, kebanyakan pengusaha kecil di Indonesia tidak menyelenggarakan dan menggunakan informasi akuntansi dalam pengelolaan usahanya. Salah seorang manajer klinik usaha kecil dan koperasi Ikatan Akuntan Indonesia (IAI), Idrus (2000), menyatakan bahwa para pengusaha kecil tidak memiliki pengetahuan akuntansi, dan banyak diantara mereka yang belum memahami pentingnya pencatatan dan pembukuan bagi kelangsungan usaha. Pengusaha kecil memandang bahwa proses akuntansi tidak terlalu penting untuk diterapkan. Dalam menjalankan aktivitas usaha seringkali orang merasa kesulitan dalam melakukan pencatatan terhadap apa yang terjadi di perusahaan. Kesulitan itu menyangkut aktivitas dan penilaian atas hasil yang di capai oleh setiap usaha. Apalagi jika harus dilakukan pengukuran dan penilaian atas aktivitas yang terjadi dalam kegiatan usaha.

Menurut Undang-Undang Nomor 20 Tahun 2008 tentang UKM, UKM didefinisikan sebagai berikut :

a. Usaha kecil adalah usaha ekonomi produktif yang berdiri sendiri, yang dilakukan oleh orang perorangan atau badan usaha yang bukan cabang perusahaan yang dimiliki, dikuasai atau menjadi bagian baik langsung maupun tidak langsung dari usaha menengah atau usaha besar yang memiliki hasil penjualan antara Rp. 300 juta 
sampai dengan Rp. 2,5 miliar dan memiliki kekayaan bersih antara Rp. 50 juta sampai dengan Rp. 500 juta.

b. Usaha menengah adalah usaha ekonomi produktif yang berdiri sendiri, yang dilakukan oleh orang perorangan atau badan usaha yang bukan merupakan anak perusahaan atau bukan cabang perusahaan yang dimiliki, dikuasai atau menjadi bagian baik langsung maupun tidak langsung dari usaha menengah atau usaha besar dengan penjualan tahunan mencapai Rp. 2,5 miliar sampai dengan Rp. 50 miliar dan memiliki kekayaan bersih lebih besar dari Rp. 500 juta.

Berdasarkan kriterianya, UKM dapat dibagi berdasarkan kepemilikan asset dan omset. Hal tersebut dapat dilihat sebagai table berikut :

\begin{tabular}{|l|l|l|l|}
\hline $\begin{array}{l}\text { Tipe Usaha } \\
\text { Kecil dan } \\
\text { Menengah }\end{array}$ & $\begin{array}{l}\text { Jumlah } \\
\text { Pegawai }\end{array}$ & $\begin{array}{l}\text { Penjualan per Tahun } \\
\text { (rupiah) }\end{array}$ & $\begin{array}{l}\text { Total Asset } \\
\text { (rupiah) }\end{array}$ \\
\hline Kecil & $5-19$ & $\begin{array}{l}>300 \text { juta }-\leq 2.500 \\
\text { juta }\end{array}$ & $>50$ juta $-\leq 500$ juta \\
\hline Menengah & $20-99$ & $\begin{array}{l}>2.500 \text { juta }-\leq 50 \\
\text { miliar }\end{array}$ & $\begin{array}{l}>500 \text { juta }-\leq 10 \\
\text { miliar }\end{array}$ \\
\hline
\end{tabular}

Tidak adanya penyelenggaraan dan penggunaan informasi akuntansi dalam kebanyakan pengelolaan usaha kecil, ditentukan oleh persepsi pengusaha kecil atas informasi akuntansi. Kreitner dan Kinicki (2001) menyatakan bahwa persepsi seseorang akan mempengaruhi perilaku dan keputusannya. Oleh karena itu, untuk dapat mendorong pengusaha kecil menyelenggarakan dan menggunakan informasi akuntansi, perlu dimulai dari persepsi pengusaha kecil tersebut terhadap informasi akuntansi.

\section{Perumusan Masalah}

Perumusan masalah dalam peneltian ini adalah : Apakah persepsi pemilik UKM berpengaruh terhadap penggunaan informasi akuntansi, dan Apakah pengetahuan akuntansi pelaku UKM berpengaruh terhadap penggunaan informasi akuntansi.

\section{Tujuan Penelitian}

Tujuan penelitian untuk menguji pengaruh variabel persepsi pemilik UKM dan pengetahuan akuntansi pelaku UKM terhadap penggunaan informasi akuntansi.

\section{Landasan Teori \\ Persepsi Pemilik}

Persepsi didefenisikan sebagai suatu proses internal yang memungkinkan untuk memilih, mengorganisasikan serta menafsirkan rangsangan dari lingkungan dan dari proses tersebut dapat mempengaruhi perilaku (Mulyana, 2001). Selanjutnya pemilik adalah individu atau sekelompok orang yang memiliki ide untuk memulai suatu bisnis dengan mengorganisasikan, mengelola, dan mengasumsikan risiko suatu bisnis yang dihadapi mulai dari permulaan bisnis (Madura, 2001). Dengan demikian persepsi pemilik merupakan proses yang dialami oleh individu atau sekelompok pebisnis dalam 
menafsirkan rangsangan dan reaksi yang diperoleh untuk dapat memahami lingkungan suatu usaha.

\section{Pengetahuan Akuntansi}

Pengetahuan merupakan persepsi jelas akan apa yang dipandang sebagai fakta, kebenaran, atau kewajiban, informasi dan/atau pelajaran yang dipelihara dan diteruskan oleh peradaban (Timotius, 2000:82). Selanjutnya Akuntansi merupakan proses pencatatan, pengelompokan dan pengikhtisaran kejadian-kejadian ekonomi dalam bentuk yang teratur dan logis dengan tujuan menyajikan informasi keuangan yang dibutuhkan untuk pengambilan keputusan (Belkaoui, 2000). Dengan demikian pengetahuan akuntansi sebagai suatu pemahaman yang jelas akan apa yang dipandang sebagai fakta, kebenaran atau informasi mengenai proses pencatatan, pengelompokan, dan pengikhtisaran kejadian-kejadian ekonomi dalam bentuk yang teratur dan logis dengan tujuan menyajikan informasi keuangan yang dibutuhkan untuk pengambilan keputusan .

\section{Penggunaan Informasi Akuntansi}

Informasi akuntansi merupakan akuntansi sebagai informasi kuantitatif tentang entitas ekonomi yang bermanfaat untuk pengambilan keputusan ekonomi dalam menentukan pilihan-pilihan diantara alternatif-alternatif tindakan (Belkaoui 2000). Selanjutnya penggunaan informasi akuntansi merupakan proses, cara, pembuatan informasi akuntansi untuk pengambilan keputusan ekonomi dalam menentukan pilihanpilihan diantara alternatif tindakan, untuk perencanaan strategis, pengawasan manajemen dan pengawasan operasional

\section{Pengaruh Persepsi Pemilik dan Pengetahuan Akuntansi Terhadap Penggunaan Informasi Akuntansi}

Persepsi pemilik persepsi dapat diartikan suatu proses dalam menafsirkan rangsangan informasi yang diperoleh untuk dapat memahami lingkungan usaha dan sekitarnya, termasuk informasi akuntansi yang akan digunakan sebagai alat untuk mengukur pencapaian dan peningkatan kinerja periode tertentu, berdasarkan pengetahuan akuntansi pemilik dalam penggunaan informasi akuntansi dalam memahami informasi-informasi akutansi yang digunakan dalam perencanaan serta pengambilan keputusan investasi.

\section{Metodologi Penelitian}

Desain penelitian merupakan penelitian kausal (Causal Research) yang merupakan penelitian untuk mengetahui pengaruh antara satu atau lebih dari variabel bebas (Independent Variable) terhadap variabel terikat (Dependent Variable). Variabel bebas (Independent Variable) adalah persepsi pemilik dengan indicator dan pengetahuan akuntansi. Sedangkan variabel terikat (Dependent variable) adalah penggunaan informasi akuntansi. 


\section{Hipotesis Penelitian}

Hipotesis adalah suatu pernyataan sementara atau dugaan yang paling memungkinkan yang masih harus dicari kebenarannya. Pengujian hipotesis ini bertujuan untuk mengetahui pengaruh persepsi pemilik dan pengetahuan akuntansi terhadap penggunaan informasi akuntansi. Adapun hipotesis yang akan diuji adalah sebagai berikut :

H01 : Tidak terdapat pengaruh persepsi pemilik terhadap penggunaan informasi akuntansi.

Ha1 : Terdapat pengaruh persepsi pemilik terhadap penggunaan informasi akuntansi.

H02 : Tidak terdapat pengaruh pengetahuan akuntansi terhadap penggunaan informasi akuntansi.

Ha2 : Terdapat pengaruh pengetahuan akuntansi terhadap penggunaan informasi akuntansi.

H03 : Tidak terdapat pengaruh secara bersama-sama persepsi pemilik dan pengetahuan akuntansi terhadap penggunaan informasi akuntansi.

Ha3 : Terdapat pengaruh secara bersama-sama persepsi pemilik dan pengetahuan akuntansi terhadap penggunaan informasi akuntansi.

\section{Populasi Dan Sampel}

Populasi penelitian seluruh pemilik UKM yang terdapat di wilayah Jakarta Barat. Metode yang digunakan adalah metode purposive sampling, dengan teknik berdasarkan pertimbangan kriteria yang diberikan adalah sebagai berikut :

a. Yang terdaftar pada Dinas Koperasi dan UMKM Kodya Jakarta Barat

b. Perusahaan UKM.

c. Usia usaha berdiri lebih dari 2 tahun.

\section{Jenis Data}

Dalam penelitian ini peneliti menggunakan data primer untuk mengukur variabel independen (persepsi pemilik dan pengetahuan akuntansi) dan variabel dependent (penggunaan informasi akuntansi) yang diambil dari individu atau perseorangan dengan menggunakan hasil pengisian kuesioner. 


\section{Operasional Variabel}

berikut :

Operasional Variabel penelitian, penelitian diuraikan dalam bentuk sebagai

\begin{tabular}{|c|c|c|}
\hline \multicolumn{3}{|c|}{ Operasional Variabel Penelitian } \\
\hline Variabel & Indikator & Skala \\
\hline $\begin{array}{l}\text { Persepsi Pemilik } \\
\text { (X1) } \\
\text { (Pinasti,2007) }\end{array}$ & $\begin{array}{l}\text { a. Perkembangan usaha } \\
\text { b. Pengambilan keputusan } \\
\text { c. Pengendalian intern usaha } \\
\text { d. Memprediksi kebutuhan kas dimasa } \\
\quad \text { yang akan datang } \\
\text { e. Perencanaan dimasa yang akan datang } \\
\text { f. Bahan pertanggung jawaban kepada pihak- } \\
\quad \text { pihak yang berkepentingan } \\
\text { g. Memperoleh pinjaman dari bank } \\
\text { h. Mengetahui posisi keuangan }\end{array}$ & Ordinal \\
\hline $\begin{array}{l}\text { Pengetahuan } \\
\text { Akuntansi } \\
\text { (X2) } \\
\text { (Bonner dan } \\
\text { Walker 2004) }\end{array}$ & $\begin{array}{l}\text { a. Pengetahuan mengenai akun-akun dalam } \\
\text { laporan keuangan } \\
\text { b. Identifikasi transaksi } \\
\text { c. Menganalisis rasio } \\
\text { d. Menyusun laporan keuangan secara akurat } \\
\text { f. Penyusunan laporan keuangan sesuai SAK } \\
\text { g. Pengetahuan dalam menyusun laporan } \\
\quad \text { sesuai peraturan perusahaan } \\
\text { h. Aturan analisis rasio } \\
\text { i. Penggunaan catatan keuangan periode } \\
\text { sebelumnya } \\
\text { j. Penerapan karakteristik f informasi akuntansi }\end{array}$ & Ordinal \\
\hline $\begin{array}{l}\text { Penggunaan } \\
\text { Informasi } \\
\text { Akuntansi } \\
\text { (Y) } \\
\text { (Holmes dan } \\
\text { Nicholls, 1989) }\end{array}$ & $\begin{array}{l}\text { a. Penggunaan meliputi buku kas masuk dan } \\
\text { keluar } \\
\text { b. Penggunaan meliputi buku persediaan } \\
\text { c. Penggunaan meliputi buku piutang } \\
\text { d. Penggunaan meliputi buku hutang } \\
\text { e. Penggunaan meliputi anggaran arus kas } \\
\text { f. Penggunaan meliputi anggaran penjualan } \\
\text { g. Penggunaan meliputi biaya produksi } \\
\text { h. Penggunaan meliputi biaya operasi } \\
\text { i. Penggunaan meliputi laporan persediaan } \\
\text { j. Penggunaan meliputi laporan gaji karyawan } \\
\text { k. Penggunaan meliputi laporan } \\
\text { jumlah produksi } \\
\text { 1. Penggunaan meliputi laporan biaya produksi }\end{array}$ & Ordinal \\
\hline
\end{tabular}




\section{Hasil dan Pembahasan}

\section{Deskripsi Data Penelitian}

Kuesioner yang disebarkan sejumlah 40 kuesioner dan jumlah kuesioner yang kembali adalah sebanyak 40 kuesioner atau 100\%. Dari 40 kuesioner yang kembali, terdapat 5 kuesioner atau 12,5\% yang tidak dapat diolah karena responden tidak memenuhi kriteria yang telah ditentukan oleh peneliti dan tidak diisi secara lengkap sehingga hanya 35 kuesioner atau $87,5 \%$ yang layak untuk diolah.

\section{Pengujian Instrumen Penelitian}

\section{Uji Reliabilitas}

Uji reliabilitas adalah alat untuk mengukur suatu kuesioner yang merupakan indikator dari variabel atau konstruk. Suatu kuesioner dapat dikatakan reliable atau handal jika jawaban seseorang terhadap pernyataan adalah konsisten atau stabil dari waktu ke waktu. Suatu konstruk atau variabel dikatakan reliable apabila memberikan nilai Cronbach's Alpha $>0,60$.

Hasil pengujian Persepsi Pemilik menunjukkan Cronbach's Alpha 0,745 > 0,60, Pengetahuan Akuntansi menunjukkan Cronbach's Alpha 0,735>0,60, dan Penggunaan Informasi Akuntansi menunjukkan Cronbach's Alpha 0,741 $>0,60$, Hal ini menunjukkan bahwa item-item pertanyaan adalah reliable.

\section{Uji Validitas}

Pengujian validitas data dimaksudkan untuk mengetahui apakah data yang terkumpul dari responden telah memenuhi syarat sebagai alat ukur yang tepat. Hal ini menunjukkan terjadinya internal konsistensi jawaban atas instrumen-instrumen kuesioner. Kriteria yang dipakai adalah $r_{\text {hitung }}$ dibandingkan dengan $r_{\text {tabel }}$. Apabila $r_{\text {hitung }}>$ $\mathrm{r}_{\text {tabel }}$ dapat disimpulkan instrumen tersebut dianggap valid.

Uji validitas ini dilakukan dengan membandingkan nilai $r_{\text {hitung }}$ dengan $r_{\text {tabel }}$ untuk df $=\mathrm{n}-\mathrm{k}-1$. Dalam penelitian ini $\mathrm{df}=35-2-1$ atau $\mathrm{df}=32$ dengan $\alpha 0,05$ didapat $\mathrm{r}_{\text {tabel }}$ sebesar 0,349. Jika $r_{\text {hitung }}$ (per item) lebih besar dari $r_{\text {tabel }}$ berarti pernyataan tersebut dikatakan valid.

Hasil uji validitas untuk Variabel Persepsi Pemilik antara 0,421-0,668 Correctedd Item-Total Correlation ( $\mathrm{r}_{\text {hitung }}$ ) untuk masing-masing item atau butir pernyataan nilainya lebih besar dari $r_{\text {tabel }} 0,349$, Variabel Pengetahuan Akuntansi antara antara 0,353-0,622 $>\mathrm{r}_{\text {tabel }}$ 0,349, Variabel Penggunaan Informasi Akuntansi antara $0,393-0,623>r_{\text {tabel }} 0,349$, maka dapat disimpulkan bahwa semua variable valid. 


\section{Uji Asumsi Klasik}

Sebelum dilakukan analisis regresi terhadap variabel- variabel penelitian terlebih dahulu dilakukan uji asumsi klasik. Tujuannya adalah agar data yang digunakan layak dijadikan sumber pengujian dan dapat dihasilkan kesimpulan yang benar. Uji asumsi klasik meliputi :

\section{Uji Normalitas}

Normalitas dapat diketahui dengan melihat tabel one-sample kolmogorov smirnov Test pada kolom Asymp sig (2-tailed) yaitu jika p value (sig) > 0,05 maka dapat disimpulkan bahwa data yang diambil dari populasi terdistribusi normal.

Hasil pengujian diperoleh hasil Asymp. Sig (2-tailed) untuk variabel persepsi pemilik $(\mathrm{X} 1)=0,719>0,05$, pengetahuan akuntansi $(\mathrm{X} 2)=0,422>0,05$ dan penggunaan informasi akuntansi $(\mathrm{Y})=0,782>0,05$, maka dapat disimpulkan data yang diambil dari populasi berdistribusi normal

2. Uji Multikolinieritas

Uji multikolinieritas dalam SPSS dilakukan dengan uji regresi, dengan nilai patokan VIF (Variance Inflation Factor) dan koefisien korelasi antarvariabel bebas (Joko Sulistyo, 2002 : 56). Untuk menguji multikolinieritas dapat dilihat dari output SPSS pada nilai tolerance dan nilai VIF (Variance Inflation Factor). Berdasarkan nilai tolerance, nilai yang terbentuk harus diatas 0,10 dan bila menggunakan VIF, nilai yang terbentuk harus kurang dari 10.

Hasil pengujian dapat diketahui bahwa nilai variance inflation factor (VIF) kedua variabel persepsi pemilik dan pengetahuan akuntansi adalah lebih kecil dari 10, dan nilai tolerance diatas 0,10 , sehingga dapat disimpulkan bahwa antar variabel persepsi pemilik dan pengetahuan akuntansi tidak mengandung multikolonieritas.

3. Uji Autokorelasi

Berdasarkan tabel statistik Durbin Watson, dengan signifikansi 0,05 dan jumlah data $(\mathrm{n})=35$, serta $\mathrm{k}=2$ ( $\mathrm{k}$ adalah jumlah variabel independen) diperoleh nilai dL sebesar 1,343 dan dU sebesar 1,584.

Hasil pengujian Dari hasil output di atas didapat nilai Durbin Watson yang dihasilkan dari model regresi adalah 1,. Karena nilai Durbin Watson 1,750 terletak diantara dU atau 1,584 dan 4-dU atau 2,416 maka hipotesis nol diterima, yang berarti tidak terdapat autokorelasi.

4. Uji Heteroskedastisitas

Untuk mendeteksi heteroskedastisitas dapat dilihat grafik scatterplot yaitu dengan melihat ada tidaknya pola tertentu pada grafik dimana sumbu $\mathrm{X}$ dan $\mathrm{Y}$ yang telah diprediksi dan sumbu $\mathrm{Y}$ adalah residual yang telah di studendized, Singgih Santoso (2000 : 210). 


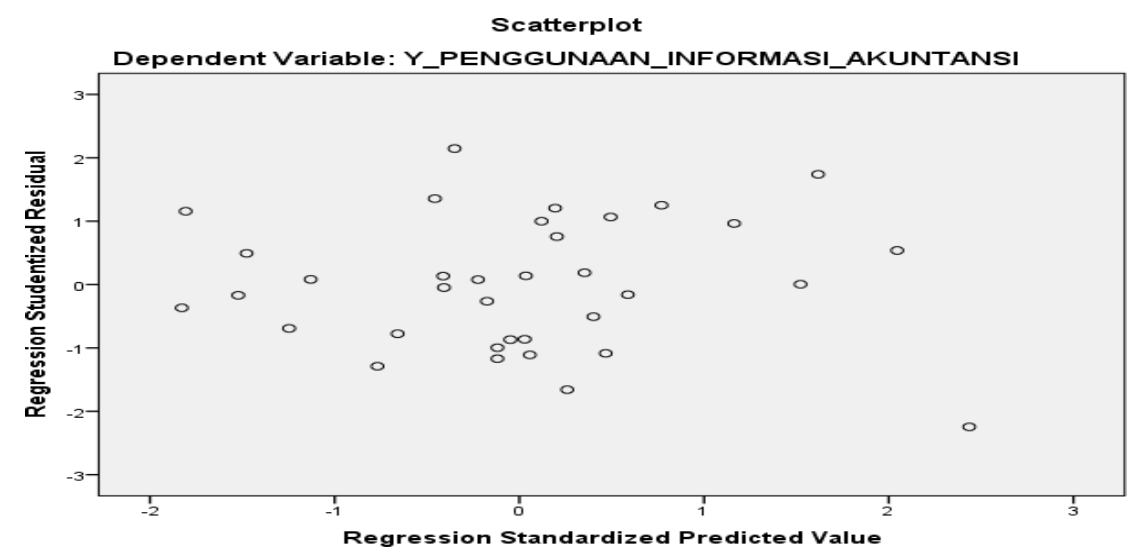

\section{Pengujian Hipotesis}

\section{Uji Hipotesis Secara Parsial (Uji t)}

Untuk mengetahui variabel independen apakah berpengaruh secara signifikan atau tidak terhadap variabel dependen dapat dilakukan dengan membandingkan $t_{\text {hitung }}$ dengan $t_{\text {tabel}}$, jika $t_{\text {hitung }}>t_{\text {tabel }}$ maka dapat disimpulkan terdapat pengaruh antara variabel independen dengan variabel dependen atau sebaliknya jika $t_{\text {hitung }}<t_{\text {tabel }}$ maka tidak terdapat pengaruh antara variabel independen terhadap variabel dependen.

$\mathrm{t}_{\text {tabel }}$ dapat dilihat pada tabel statistik pada signifikansi 0,05 dengan derajat kebebasan $(\mathrm{df})=\mathrm{n}-\mathrm{k}-1=35-2-1=32$. Hasil yang diperoleh untuk $\mathrm{t}_{\text {tabel }}$ sebesar 1,694, sedangkan $\mathrm{t}_{\text {hitung }}$ dapat dilihat dari hasil output SPSS pada tabel coefficient :

\section{Coefficients $^{\mathrm{a}}$}

\begin{tabular}{|c|c|c|c|c|c|c|c|}
\hline \multirow[b]{2}{*}{ Model } & \multicolumn{2}{|c|}{$\begin{array}{l}\text { Unstandardized } \\
\text { Coefficients }\end{array}$} & \multirow{2}{*}{$\begin{array}{l}\text { Standard } \\
\text { i zed } \\
\text { Coefficie } \\
\text { nts } \\
\text { Beta }\end{array}$} & \multirow[b]{2}{*}{$\mathrm{t}$} & \multirow[b]{2}{*}{ Sig. } & \multicolumn{2}{|c|}{$\begin{array}{l}\text { Collinearity } \\
\text { Statistics }\end{array}$} \\
\hline & B & $\begin{array}{l}\text { Std. } \\
\text { Erro } \\
\mathrm{r}\end{array}$ & & & & $\begin{array}{l}\text { Tolera } \\
\text { n ce }\end{array}$ & VIF \\
\hline $1 \quad$ (Constant) & \begin{tabular}{|l|}
251,36 \\
7
\end{tabular} & 111,266 & & $\begin{array}{l}2,25 \\
9\end{array}$ & ,031 & & \\
\hline Persepsi & & & ,092 &, 584 & ,563 & ,915 & $\begin{array}{l}1,09 \\
3\end{array}$ \\
\hline Pemilik (X1) & & & & & & & \\
\hline $\begin{array}{l}\text { Pengetahuan } \\
\text { Akutansi } \\
\text { (X2) }\end{array}$ & ,657 & ,213 & ,488 & $\begin{array}{l}3,09 \\
4\end{array}$ & ,004 & ,915 & $\begin{array}{l}1,09 \\
3\end{array}$ \\
\hline
\end{tabular}

a. Dependent Variable: Penggunaan Informasi Akuntansi (Y)

Sumber data:Output SPSS diolah oleh penulis, 2016 
Berdasarkan tabel tersebut, selanjutnya penulis melakukan pengujian hipotesis secara parsial (uji t) masing-masing variabel penelitian yaitu sebagai berikut :

\section{Persepsi Pemilik (X1) Terhadap Penggunaan Informasi Akuntansi (Y)}

Hipotesis penelitian yang akan di uji adalah sebagai berikut:

$\mathrm{Ho}_{1}$ : Tidak terdapat pengaruh persepsi pemilik terhadap penggunaan informasi akuntansi.

$\mathrm{Ha}_{1}$ : Terdapat pengaruh pengaruh persepsi pemilik terhadap penggunaan informasi akuntansi.

Pada tabel 4.19 coefficients diperoleh $t_{\text {hitung }}$ variabel persepsi pemilik sebesar 0,584, kemudian dibandingkan dengan $t_{\text {tabel }}$ sebesar 1,694 ternyata nilai $\mathrm{t}_{\text {hitung }}(0,584)<\mathrm{t}_{\text {tabel }}(1,694)$, maka Ho diterima dan Ha ditolak, artinya bahwa persepsi pemilik tidak berpengaruh terhadap penggunaan informasi akuntansi.

Hasil pengujian juga dapat dilihat dari nilai signifikan persepsi pemilik yaitu sebesar 0,563 lebih besar dari tingkat signifikan 0,05 , yang artinya secara parsial persepsi pemilik tidak berpengaruh terhadap penggunaan informasi akuntansi.

\section{Pengetahuan Akuntansi (X2) Terhadap Penggunaan Informasi Akuntansi (Y)}

Hipotesis penelitian yang akan di uji adalah sebagai berikut:

$\mathrm{Ho}_{2}$ : Tidak terdapat pengaruh pengetahuan akuntansi terhadap penggunaan informasi akuntansi.

$\mathrm{Ha}_{2}$ : Terdapat pengaruh pengetahuan akuntansi terhadap penggunaan informasi akuntansi.

Pada tabel coefficients diperoleh $t_{\text {hitung }}$ variabel pengetahuan akuntansi sebesar 3,094, kemudian dibandingkan dengan $t_{\text {tabel }}$ sebesar 1,694 ternyata nilai $t_{\text {hitung }}(3,094)>t_{\text {tabel }}$ $(1,694)$, maka Ho ditolak dan Ha diterima, artinya bahwa pengetahuan akuntansi berpengaruh terhadap penggunaan informasi akuntansi.

Hasil pengujian juga dapat dilihat dari nilai signifikan pengetahuan akuntansi yaitu sebesar 0,004 lebih kecil dari tingkat signifikan 0,05. Hasil ini mengindikasikan bahwa pengetahuan akuntansi berpengaruh terhadap penggunaan informasi akuntansi

\section{Uji Hipotesis Secara Simultan (Uji F)}

Uji $\mathrm{F}$ digunakan untuk mengetahui ada tidaknya pengaruh secara bersama-sama (simultan) variabel bebas yaitu persepsi pemilik $\left(\mathrm{X}_{1}\right)$, pengetahuan akuntansi $\left(\mathrm{X}_{2}\right)$ terhadap variabel terikat yakni penggunaan informasi akuntansi (Y). Uji F dilakukan dengan cara membandingkan $\mathrm{F}_{\text {hitung }}>\mathrm{F}_{\text {tabel }}$ dimana $\mathrm{F}_{\text {hitung }}$ diperoleh dari hasil Output SPSS dalam Anova, sedangkan $\mathrm{F}_{\text {tabel }}$ diperoleh dari tabel df penyebut $=\mathrm{n}-\mathrm{k}-1=35-2-1=$ 32 , df pembilang $=\mathrm{k}=2$, yaitu Ftabel $=3,29$. Hasil Output SPSS untuk $\mathrm{F}_{\text {hitung }}$ disajikan pada tabel di bawah ini. 


\section{ANOVA ${ }^{\mathrm{a}}$}

\begin{tabular}{|ll|l|l|l|l|l|}
\hline \multicolumn{2}{|l|}{ Model } & $\begin{array}{l}\text { Sum of } \\
\text { Squares }\end{array}$ & df & $\begin{array}{l}\text { Mean } \\
\text { Square }\end{array}$ & F & Sig. \\
\hline 1 & Regression & 43097,551 & 2 & 21548,776 & 5,992 & $\begin{array}{l}, 006 \\
\mathrm{~b}\end{array}$ \\
& $\begin{array}{l}\text { Residual } \\
\text { Total }\end{array}$ & 115075,593 & 32 & 3596,112 & & \\
& 158173,144 & 34 & & & \\
\hline
\end{tabular}

a. Dependent Variable: Penggunaan Informasi Akuntansi (Y)

b. Predictors: (Constant), Persepsi Pemilik (X1), Pengetahuan Akuntansi (X2)

Sumber data:Output SPSS diolah oleh penulis, 2016

Berdasarkan tabel $A N O V A^{a}$ dapat disimpulkan bahwa hasil $\mathrm{F}_{\text {hitung }}$ sebesar 5,992 dengan tingkat signifikansi 0,006 , artinya $F_{\text {hitung }}>F_{\text {tabel }}(5,992>3,29)$, dengan demikian $\mathrm{H} 0$ ditolak dan Ha diterima, sehingga terbukti bahwa persepsi pemilik dan pengetahuan akuntansi berpengaruh signifikan terhadap penggunaan informasi akuntansi.

\section{KESIMPULAN}

Berdasarkan hasil penelitian ini mengenai persepsi pemilik dan pengetahuan akuntansi pelaku usaha kecil dan menengah atas penggunaan informasi akuntansi yang dilakukan pada perusahaan Usaha Kecil dan Menengah di wilayah Jakarta Barat, maka dapat ditarik kesimpulan sebagai berikut :

1. Berdasarkan hasil uji f (uji secara simultan) variabel persepsi pemilik (X1) dan pengetahuan akuntansi (X2) mempunyai pengaruh yang signifikan terhadap penggunaan infornasi akuntansi (Y).

2. Berdasarkan hasil uji t (uji secara parsial) variabel persepsi pemilik (X1) tidak mempunyai pengaruh yang signifikan terhadap penggunaan informasi akuntansi (Y).

3. Berdasarkan hasil uji t (uji secara parsial) variabel pengetahuan akuntansi (X2) mempunyai pengaruh yang signifikan terhadap penggunaan informasi akuntansi (Y). 


\section{DAFTAR PUSTAKA}

Abubakar, Arif dan Wibowo. 2005. Akuntansi untuk Bisnis Usaha Kecil dan Menengah. PT Grasindo, Jakarta.

Azhar, La Midjan dan Susanto. 2001. Sistem Informasi Akuntansi I dan II., Edisi Ke Sebelas, Lembaga Informatika, Bandung.

Belkaoui, A.R. 2000. Teori Akuntansi. Edisi Pertama, Salemba Empat, Jakarta.

Budi, Chandra. 2013. Jutaan UMKM Pahlawan Pajak Urus Pajak Itu Sangat Mudah, PT Elex Media Komputindo, Jakarta.

Ghozali, Imam. 2011. Aplikasi Analisis Multivariate Dengan Program IBM SPSS 19. (Edisi Kelima) Semarang, Universitas Diponegoro.

Ghozali, Imam. 2013. Aplikasi Analisis Multivariate dengan Program IBS SPSS 21 Update PLS Regrsi, Badan Penerbit Universitas Diponegoro, Semarang.

Hansen dan Mowen. 2005. Management Accounting. Salemba Empat. Jakarta. Harahap, Sofyan Syafri. 2011. Teori Akuntansi, PT Raja Grafindo Persada, Jakarta.

Hariyanto. 1999. Kebutuhan Informasi Akuntansi Bagi Usaha Perdagangan Eceran (Retail) Di Kotatip Purwokerto. Universitas Diponegoro Semarang.

Holmes, S., and Nicholls, D. 1988. An Analysis of The Use of Accounting Information by Australian Small Business Journal of Small Business Management, 26 (20), 57-68.

IAI. 2001. Standar Profesional Akuntan Publik. Salemba Empat, Jakarta.

Johnson H.T. and Kaplan R.S. (1987), Relevance Lost: the Rise and Fall of Management Accounting, Harvard Business School Press, Boston, US.

Kartikahadi, Hadi., et al. 2012. Akuntansi Keuangan Berdasarkan SAK Berbasis IFRS, Salemba Empat, Jakarta.

Kementerian Koperasi dan UMKM, 2012.

Kiryanto, dkk. 2001. Pengaruh Persepsi Manajer Atas Informasi Akuntansi Keuangan Terhadap Keberhasilan Perusahaan Kecil. Jurnal Riset Akuntansi Indonesia Vol.4/No.2/2001. Yogyakarta, Fakultas Ekonomi dan Bisnis Universitas Gajah Mada.

Kreitner, Robert and Angelo Kinicki. 2001. Organizational Behavior. Fifth Edition. Irwin McGraw-Hill.

Linda, 2012. Analisis Dampak Kredit Mikro Terhadap Perkembangan Usaha Mikro Di Kota Semarang. Skripsi S1, Program Sarjana Fakultas Ekonomika dan Bisnis Universitas Diponegoro.

Mulyana, Deddy. 2001. Ilmu Komunikasi Suatu Pengantar.

Nugroho, Widjajanto. 2001. Sistem Informasi Akuntansi. Erlangga, Jakarta. Sariningtyas, Pratiwi dan Tutik Diah W. 2011. Standar Akuntansi Keuangan Entitas Tanpa Akuntabilitas Publik pada Usaha Kecil dan Menengah. JAKI, Vol.1 No.1: 90-101.

Setyawan, Purnomo. 2007. Menumbuhkan Kebiasaan Menyusun Laporan Keuangan pada Usaha Kecil dan Menengah.

Sulistyo, Joko. 2002. 6 Hari Jago SPSS 17, Penerbit Cakrawala, Yogyakarta.

Umar, Husein. Metode Riset Komunikasi Organisasi Jakarta. PT Gramedia Pustaka Utama, 2003

Undang-Undang Nomor 20 Tahun 2008 Tentang Usaha Mikro, Kecil dan Menengah. 